\title{
TREE CANOPY AND BLACK PLASTIC COVER ON FLOWERING, GROWTH, AND YIELD OF SOME PEAS
}

\author{
Novika Ayu Lestari ${ }^{1}$, Supriyono ${ }^{2 *}$, Eddy Triharyanto $^{2}$, and Sri Nyoto ${ }^{2}$ \\ ${ }^{1}$ Undergraduate Student Study Program of Agrotechnology, Faculty of Agriculture, Sebelas Maret \\ University Surakarta \\ ${ }^{2}$ Department of Agrotechnology, Faculty of Agriculture, Sebelas Maret University Surakarta \\ Submitted: 2018-11-26 Accepted: 2019-09-10
}

\begin{abstract}
Field bean (Dolichos lablab), adzuki bean (Vigna angularis), pigeon pea (Cajanus cajan) and winged bean (Psophocarpus tetragonolobus) are a group of peas or legumes which used as an alternative food beside groundnut, soybean or mung bean. The day length or planting season is one factor that affects plants to flower. Long day or bean offseason can inhibit plants to flower, especially for short-day plants. covering the plant from sunlight may trigger a quick flowering of plants. The purpose of this research was to find out how to prompt plants to flower, growth, and yield during the off-season period in a very short time. This research was conducted by using a Randomized Completed Block Design (RCBD) with 2 factors. The first factor was shortening the day length (control, black plastic cover for 2 hours day $^{-1}$, plant under trees canopy covered) and the second factor was some kind of peas (field bean, adzuki bean, pigeon pea, and winged bean). Black plastic cover was used 2 hours a day ${ }^{-1}$ during 30 days after 14 days of plantation. The research was replicated 3 times. The results showed that field bean combinations with control and plastic closure gave a higher number of pods. For all field bean treatments, plastic-closure on pigeon pea and also winged bean provided higher straw fresh weight than control and plastic closure on adzuki bean and winged bean under the tree. Covering plants using plastic for 2 hours day ${ }^{-1}$ tends to increase e the total flowering number and seed yield at each plant. The growth component showed that field bean was higher than adzuki bean, winged bean, and pigeon pea. The effort to shorten a long day plantation had no significant effect on many variables due to climate anomaly in the 2017 rain show on start to finish this year. However, pigeon pea did not have flowers when planted on a long day or offseason period.
\end{abstract}

Keywords: Flowering Induction, Legume, Photoperiod

How to Cite: Lestari, N. A., Supriyono, Triharyanto, E., and Nyoto, S. (2019). Tree Canopy and Black Plastic Cover on Flowering, Growth, and Yield of Some Peas. Sains Tanah Journal of Soil Science and Agroclimatology, 16(2): 139-146 (doi: 10.20961/stjssa.v16i2.25546)

Permalink/DOI: http://dx.doi.org/10.20961/stjssa.v16i2.25546

\section{INTRODUCTION}

Field bean (Dolichos lablab), adzuki bean (Vigna angularis), pigeon pea (Cajanus cajan) and winged bean (Psophocarpus tetragonolobus) are unpopular peas, bean or legumes. Those plants can be used as

\footnotetext{
* Corresponding Author :

Email:supriyono_uns@yahoo.com
}

alternative food sources other than imported peanuts like soybeans and mung beans. Various types of beans (legumes) are an important source of vegetable protein for millions of people in tropical and subtropical regions, especially in poor and developing countries. Compared to animal protein, 
vegetable protein derived from cheaper plants, is more available, and the need for vegetable protein is very important in the future (Mao \& Hynniewta, 2000). Pigeon Pea (Cajanus cajan) is grown on 5 million ha in more than 50 countries (Wanjari \& Rathod, 2012). Cajanus cajan is rich in protein (20-22\%), and its seeds are the main food source for Indian people (Ramanujam \& Singh, 1981). Delichos lablab is not a well-recognized legume, so the research about it is limited, even though it can be served as food, animal feed, medicine, green fertilizer, and can be used as well for environmental conservation (Cobley, 1977).

The control of flower formation by day length is called photoperiodism. This term is sometimes referred to the length of the day associated with irradiation and plant growth. Photoperiodicity controls the initiation of flower formation (Lang, 1965). Climate factors that affect flowering are not only day length but also temperatures. Short heat stress can cause a significant increase in the frequency of flower and flower bud abortions in nuts, but a large variability of sensitivity exists between reproductive organs in plants or between plants (Guilioniet et al., 1997). Thus, a short hot temperature can even suppress flower formation.

Long days or long nights are one of the factors that cause plants to flower. The length of day and the length of irradiation that is not suitable will prevent flowering from happening. Flowering Induction is thus necessary for hope that plants that naturally do not want to flower will be able to produce flowers. One way to trigger flowering in shortday plants is to reduce the duration of irradiation in a day (Kofranek, 1980).

The results of previous studies indicate that cowpeas planted in Central Java from early November to January does not flower, as well as planting period from January to April does not also produce flowers. Velvet peanuts in the rice fields of Gunung Kidul district are planted in November and April and are harvested at the end of August (Supriyono, 2007). This is because various non-conventional nuts are short-day crops. Indeed, for peanut plants cultivated and touched by plant breeding, namely peanuts, soybeans, and green beans, they can flower throughout the year. However, it turned out that this did not happen to velvet beans and cowpeas. For this reason, the influence of a long day needs to be tested for other types of beans. In Java, the shortest day occurs on June 21 when the sun is further enough, i.e. at $23.5^{\circ} \mathrm{N}$. Corn as intercropping can cause flowering of cowpeas during the offseason. The fastest flowering occurs at a spacing of $25 \mathrm{~cm} \times 60 \mathrm{~cm}$, while the highest number of seeds occurs at a spacing of $40 \mathrm{~cm} x$ $100 \mathrm{~cm}$. Intercropping of corn does not significantly reduce the quantity of cowpea yield. There is a tendency for the best seed yield to occur in the intercropping spacing of corn $40 \mathrm{~cm} \times 60 \mathrm{~cm}$, because of the high weight of 1000 seeds in 2010, plastic closure of 2 hours in the morning, afternoon and evening did not increase flowering because the same amount of flower also founded in control plants. This is due to weather anomalies, year-round rain and research carried out in greenhouses to reduce heat as the location of the gauze are closed (Supriyono, 2012).

Velvet beans and cowpeas are proven to be short-day plants, capable of producing flowers when the length of the day is less than the critical period. This study aims to determine the effectiveness of black plastic closure and/or under trees placement to stimulate the flowering of field beans, adzuki beans, pigeon peas, and winged beans during the off-season period.

\section{MATERIALS AND METHODS}

This research was carried out on the experimental land of Sukosari Village, 
Jumantono Subdistrict, Karanganyar Regency from September 2017 to January 2018. This location is located at $7^{\circ} 37^{\prime} 48.3^{\prime \prime} S$ and $110^{\circ} 56^{\prime} 51.2^{\prime \prime} E$ with an altitude of 170 meters above sea level (masl) and using Alfisol soil types. The material used was seeds of Field bean (Dolichos lablab), Adzuki bean (Vigna angularis), pigeon pea (Cajanus cajan) and winged bean (Psophocarpus tetragonolobus), soil, compost, and water. The tools used were polybags, black plastic hoods, props, analytical scales, ovens, lux meters, and thermohygrometer.

The study used a Randomized Complete Block Design (RCBD) with two factors, namely treatment of the length of the day and the type of legume. The first factor is an effort to shorten the day length, consists of 3 levels (control, 2 hours per day with black- plastic cover, planted under trees). The covering of 2 hours of black plastic per day was carried out when the plant was 30 days old for 14 days in the morning. The second treatment factor was given to 4 types of legumes, namely field bean (Dolichos lablab), adzuki bean (Vigna angularis), pigeon pea (Cajanus cajan), and winged bean (Psophocarpus tetragonolobus). Data from the study were analyzed by using Analysis of Variance (ANOVA) with a level of $5 \%$ and continued with Duncan's Multiple Range Test (DMRT). Observation variables include plant height, number of leaves, start of flowering, number of flowers, appearance of pods, number of pods, number of seeds per pod, number of seeds per plant, seed weight per plant, weight of 100 seeds, weight of fresh straw, weight of dry straw, root shoot ratio, and climatic conditions.

The closure was carried out covering the entire plant with a black plastic bag of $80 \mathrm{~cm}$ wide with a pouch below. The plants were covered from the top of the plant as high as 1.5 $\mathrm{m}$ to the ground. The black plastic used is a black plastic roll. Covering starts when the plants are 30 days old for 14 days (26 October 2017 to 8 November 2017). Then, it was sealed by closing the plants for 2 hours a day from 8:00 to 10:00 a.m. Planting under trees is done in the south of the mango tree with a canopy as high as $2-5 \mathrm{~m}$. The results of the observation of the microclimate conditions for each treatment are presented in Table $1 \mathrm{~b}$.

Table 1. Environmental data of the research location a. Data of climatic during field research

\begin{tabular}{lcccc}
\hline Month & $\begin{array}{c}\text { Air Temperature } \\
\left({ }^{\circ} \mathbf{C}\right)\end{array}$ & $\begin{array}{c}\text { Air Humidity } \\
(\mathbf{\%})\end{array}$ & $\begin{array}{c}\text { Irradiation } \\
(\mathbf{\%})\end{array}$ & $\begin{array}{c}\text { Rainfall } \\
(\mathbf{m m})\end{array}$ \\
\hline September 2017 & 28.17 & 84.68 & 61.53 & 17 \\
October 2017 & 27.76 & 83.56 & 54.86 & 188 \\
November 2017 & 27.53 & 85.31 & 31.82 & 438 \\
December 2017 & 27.87 & 83.78 & 45.43 & 293 \\
January 2018 & 27.18 & 84.90 & 32.36 & 390 \\
\hline Average & 27.70 & 84.45 & 45.20 & 265.20 \\
\hline
\end{tabular}

b. The average estimate of the light intensity, temperature, and humidity in various treatments

\begin{tabular}{lccc}
\hline Treatment \Average treatment for plastic closure & $\begin{array}{c}\text { Light Intensity } \\
(\text { (lux) }\end{array}$ & $\begin{array}{c}\text { Temperature } \\
\left({ }^{\circ} \mathbf{C}\right)\end{array}$ & $\begin{array}{c}\text { Relative Humidity } \\
(\%)\end{array}$ \\
\hline Control & 30872.730 & 30.68 & 61.73 \\
Plastic closure & 1394.545 & 32.05 & 56.00 \\
Under the tree & 9766.364 & 29.73 & 73.27 \\
\hline
\end{tabular}




\section{RESULTS}

\section{General description of the location of the research}

Various pea growing seasons in Java are generally from April to August. The study was conducted in off-season i.e. September to January. It turned out that the plantation occurred outside this season causing an increase in the average temperature from 27 to $27.7{ }^{\circ} \mathrm{C}$, humidity from 72.9 to $84.45 \%$, decreased irradiation from 53.4 to 45.2 and increased rainfall from 23.84 to 53.04 month $^{-1}$. Indeed, the characteristics of the rainy season are seen in the planting outside this season, but in 2017 this is supposed to be the dry season; when planting various beans, there is still rain even though it is relatively small (Table 1a). The black plastic closure turned out to lower the light intensity from 30872.73 lux to 1394.55 lux and this was expected to be as night. The planting under the tree lowered the solar intensity from 30872.73 lux to 9766.36 (lux). This reduction will become apparent in the morning and evening when the intensity is low so that it assumed as night condition. Plastic closure increases the temperature but decreases moisture, while planting under trees lowers temperature but increases humidity (Table 1b).

Table 2. The total number of pods per plant and the fresh weight of straw per plant on a Legume type and shortening the day length

\begin{tabular}{lcc}
\hline Treatment & Total pods number & Fresh strawweight (g) \\
\hline Field bean - control & $36.22 \mathrm{~b}$ & $210.66 \mathrm{~d}$ \\
Field bean - plastic-covered & $30.67 \mathrm{~b}$ & $178.89 \mathrm{~cd}$ \\
Field bean - under tree & $12.89 \mathrm{a}$ & $183.44 \mathrm{~cd}$ \\
Adzuki pea- control & $12.33 \mathrm{a}$ & $16.45 \mathrm{a}$ \\
Adzuki pea - plastic-covered & $10.44 \mathrm{a}$ & $20.00 \mathrm{a}$ \\
Adzuki pea - under tree & $6.11 \mathrm{a}$ & $29.11 \mathrm{ab}$ \\
Winged bean - control & $2.67 \mathrm{a}$ & $64.56 \mathrm{abc}$ \\
Winged bean - plastic-covered & $1.11 \mathrm{a}$ & $168.56 \mathrm{bcd}$ \\
Winged bean - under tree & $1.11 \mathrm{a}$ & $15.67 \mathrm{a}$ \\
Pigeon pea - control & $.00 \mathrm{a}$ & $157.22 \mathrm{abcd}$ \\
Pigeon pea - plastic-covered & $.00 \mathrm{a}$ & $175.78 \mathrm{~cd}$ \\
Pigeon pea - under tree & $.00 \mathrm{a}$ & $123.57 \mathrm{abcd}$ \\
\hline
\end{tabular}

Remarks: number followed by the same letter in the column, is not significantly different based on the Duncan Test $\alpha=0.05, \mathrm{~g}=$ gram

The effect of pea types and length of day

In Table 2, 2 variables interact which were bean types and day length reduction from 13 observed variables. In the field bean case, placement under a tree decreases the total number of pods, whereas, in other beans, the administered treatment does not change the variable. Unlike other beans, pigeon pea does not produce pods in both treatment and control. In the field bean, adzuki pea and pigeon pea, the treatment of plastic closure and placement under the tree does not change the weight of fresh straw. The fresh field bean weight is not significantly different from pigeon pea and is higher than adzuki bean. Winged bean plastic closure increases the fresh weight of straw compared to placement under the tree canopy.

\section{The effect of day length}

In Table 3, plastic closure increases the amount of flower per plant even though it is not significantly different from control. The treatment of plastic closure turned out to increase the weight of seed yield per plant, both for control and placement under the tree canopy. The treatment of reducing the length 
of the day, both with plastic closure and placement under the tree canopy did not significantly change the growth of variables and other results.

\section{Type of pea}

In Table 4, it is presented that the highest crop was field bean followed by winged bean, pigeon pea, and adzuki bean. The highest number of leaves was also field bean which was not significantly different from the winged bean, followed by pigeon pea and lowest adzuki bean. Pigeon pea does not produce flowers, pods, and seeds. The fastest flowering speed is the field bean and winged bean, followed by adzuki bean. Field bean has the most flower followed by adzuki bean and the lowest was winged bean. The appearance of the fastest pod was seen in field bean and winged bean followed by adzuki bean. The highest number of pods was found in field bean followed by adzuki bean and the lowest was in winged bean. The number of seeds per pod is abundant in the field bean and is not significantly different from adzuki bean; field bean is higher than winged bean. The highest number of seeds per plant was field bean followed by adzuki bean and lowest winged bean. Seed weight per plant and weight of 100 seeds are not significantly different between field bean and adzuki bean but higher than winged bean. The highest field bean fresh weight is followed by winged bean and the lowest was pigeon pea and adzuki bean. The highest field bean straw dry weight was not significantly different from winged bean and the lowest was adzuki bean. Root shoot ratio was higher adzuki bean and pigeon pea than field bean and winged bean.

\section{DISCUSSION}

The results showed that the closure of black plastic in 2 hours a day had no significant effect on the initial number of flowering field beans, which accelerated the time of flowering during 4 weeks (6.83 wap) compared to control. But tree cover reduces the amount of flower from 20.28 to 12.89 per plant. Peanut fields bloom in September-February (Kukade \& Tidke, 2014). Parmar et al. (2013) stated that Dolichos lablab is sensitive to sunlight and has extensive adaptability to environmental conditions (Kimani et al., 2012). According to Bernier et al. (1993) in the treatment of short days, sucrose and protein in leaves will cause meristems to form buds. Wilkins (1989) states that the reduction in midday light intensity is considered to reduce photo-respiration activity so that the net result of photosynthesis is higher. This stimulates generative growth, namely the formation of flower primordia. According to Nelza (2016), plants that grow in shady conditions have more flower buds than those planted without shade. Supriyono (2012) shows that although it does not produce significantly different results, the reduction in day length tends to increase the amount of interest per plant. Kramer and Kozlowski (1979) state that differences in shade levels affect the intensity of light causing the intensity of light received by plants to be different.

Plants that are given shade or sealing cover tend to be higher because of etiolation. This result is in accordance with Loveless (1991) statement asserting that plants will grow taller when planted in the shade. Addition of plant height is influenced by one of the hormones, namely auxin. Salisbury and Ross (1995) add that plants affected by the shade will experience cell elongation, especially on the stem. This happens because the production of auxin in shoots increases so that it stimulates the elongation of plant cells. Chairudin et al. (2015) state that plants that cannot adapt to low light intensity will have fewer leaves, whereas according to MüllerMoulé et al. (2004) leaves of plants that cannot adapt to high light intensity will experience 
symptoms of chlorosis, and have a smaller size and more amount a little.

It turns out that the total number of pods in the Field bean control and plastic lid is higher than other treatments and also Field bean under the tree. From the data distribution, it can be seen that the original field beans are capable of producing more total pods than other beans (Table 2). Pigeon beans do not produce pods as velvet bean and cowpea in previous studies, indicating that the responsiveness of pigeon beans to day length is very high. The weight of fresh field bean straw in various day length treatments is higher than that of adzuki beans and winged beans under the tree. This shows that genetically the body of the field bean plant is larger. The response of winged beans on light reduction is higher than other nuts.

Table 3. Variable growth, flowering, and yield in treatment shorten day length

\begin{tabular}{lrrr}
\hline Variable/Treatment & Control & Black Plastic Cover & Canopy trees covered \\
\hline Plant height $(\mathrm{cm})$ & $195.67 \mathrm{a}$ & $214.85 \mathrm{a}$ & $187.75 \mathrm{a}$ \\
Leaf number & $87.86 \mathrm{a}$ & $90.56 \mathrm{a}$ & $68.39 \mathrm{a}$ \\
First day flowering (wap) & $6.40 \mathrm{a}$ & $6.18 \mathrm{a}$ & $6.56 \mathrm{a}$ \\
Total flower number & $20.28 \mathrm{ab}$ & $24.36 \mathrm{~b}$ & $12.89 \mathrm{a}$ \\
First day pods showing & $6.93 \mathrm{a}$ & $7.14 \mathrm{a}$ & $7.89 \mathrm{a}$ \\
Total pods number & $10.86 \mathrm{a}$ & $10.94 \mathrm{a}$ & $6.58 \mathrm{a}$ \\
Seed number per pods & $1.67 \mathrm{a}$ & $2.50 \mathrm{a}$ & $1.62 \mathrm{a}$ \\
Seed number per plant & $10.58 \mathrm{a}$ & $12.82 \mathrm{a}$ & $9.83 \mathrm{a}$ \\
Seed weight per plant $(\mathrm{g})$ & $2.57 \mathrm{a}$ & $4.24 \mathrm{~b}$ & $2.85 \mathrm{a}$ \\
Weight of 100 seed $(\mathrm{g})$ & $14.86 \mathrm{a}$ & $21.29 \mathrm{a}$ & $16.64 \mathrm{a}$ \\
Weight of fresh straw $(\mathrm{g})$ & $325.58 \mathrm{a}$ & $279.22 \mathrm{a}$ & $293.53 \mathrm{a}$ \\
Weight of dry straw $(\mathrm{g})$ & $112.22 \mathrm{a}$ & $135.81 \mathrm{a}$ & $87.94 \mathrm{a}$ \\
Root shoot ratio & $.11 \mathrm{a}$ & $.13 \mathrm{a}$ & $.1675 \mathrm{a}$ \\
\hline
\end{tabular}

Remarks: number followed by the same letters in rows, are not significantly different based on Duncan Test $\alpha=0.05 . \mathrm{cm}=$ centimeter, wap $=$ week after planting, $\mathrm{g}=$ gram

Table 4. Variable growth, flowering, and yield on various types of legumes

\begin{tabular}{lrrrr}
\hline Variable/Treatment & Field bean & Adzuki bean & Pigeon pea & Winged bean \\
\hline Plant height (cm) & $340.30 \mathrm{~d}$ & $45.42 \mathrm{a}$ & $114.52 \mathrm{~b}$ & $297.44 \mathrm{c}$ \\
Leaf number & $117.15 \mathrm{c}$ & $17.92 \mathrm{a}$ & $81.41 \mathrm{~b}$ & $112.59 \mathrm{c}$ \\
First day flowering (wap) & $9.80 \mathrm{c}$ & $4.96 \mathrm{~b}$ & $.00 \mathrm{a}$ & $10.81 \mathrm{c}$ \\
Total flower number & $40.11 \mathrm{c}$ & $26.04 \mathrm{~b}$ & $.00 \mathrm{a}$ & $10.56 \mathrm{a}$ \\
First day pods showing & $9.63 \mathrm{c}$ & $1.63 \mathrm{~b}$ & $.00 \mathrm{a}$ & $10.81 \mathrm{c}$ \\
Total pods number & $26.59 \mathrm{c}$ & $9.63 \mathrm{~b}$ & $.00 \mathrm{a}$ & $1.63 \mathrm{a}$ \\
Seed number per pods & $3.31 \mathrm{c}$ & $2.56 \mathrm{bc}$ & $.00 \mathrm{a}$ & $1.85 \mathrm{~b}$ \\
Seed number per plant & $24.67 \mathrm{~d}$ & $14.87 \mathrm{c}$ & $.00 \mathrm{a}$ & $4.78 \mathrm{~b}$ \\
Seed weight per plant $(\mathrm{g})$ & $5.84 \mathrm{c}$ & $4.91 \mathrm{c}$ & $.00 \mathrm{a}$ & $2.13 \mathrm{~b}$ \\
Weight of 100 seed $(\mathrm{g})$ & $24.56 \mathrm{c}$ & $30.73 \mathrm{c}$ & $.00 \mathrm{a}$ & $15.09 \mathrm{~b}$ \\
Weight of fresh straw $(\mathrm{g})$ & $619.14 \mathrm{c}$ & $43.37 \mathrm{a}$ & $117.78 \mathrm{a}$ & $417.48 \mathrm{~b}$ \\
Weight of dry straw $(\mathrm{g})$ & $191.00 \mathrm{c}$ & $21.85 \mathrm{a}$ & $82.93 \mathrm{ab}$ & $152.19 \mathrm{bc}$ \\
Root shoot ratio & $.08 \mathrm{a}$ & $.20 \mathrm{~b}$ & $.17 \mathrm{~b}$ & $.09 \mathrm{a}$ \\
\hline
\end{tabular}

Remarks: number followed by the same letters are not significantly different based on Duncan Test $\alpha=0.05$, $\mathrm{cm}=$ centimeter, wap $=$ week after planting, $\mathrm{g}=$ gram

Compared to Adzuki and Pigeon beans, plant growth and peanut canopy were faster, but the weight of 100 seeds and seed weight per plant were not significantly different from adzuki beans. This is possible because Field Bean has hereditary factors that are vegetatively larger. Field bean crops are the highest, but the number of leaves and dry 
weight of straw is not significantly different from winged beans. The results of the field bean crop are also higher than winged beans. Pigeon beans do not produce pods until the end of the study (Table 4). This is due to out-ofseason plantings such as velvet beans and cowpea (Supriyono, 2012). Dong et al. (2016) stated that short photoperiods affected the reduction in the number of days from seeding to flowering and the adult phase, also began the process of differentiating flower buds in Adzuki beans. Harris (1992) explains that increasing the shoot root ratio is a response to more suitable growth conditions. Increased root canopy ratio indicates that plants grow in inappropriate conditions.

\section{CONCLUSION}

The total number of flowers in the black plastic cover treatment was higher than the treatment under the tree. The closure of black plastic and placement under the tree did not change the fresh weight of straw on the field bean, adzuki bean, and pigeon pea but increased the winged bean variable compared to the tree placement. Black plastic closure increases the number of total field bean pods compared to placement under a tree. The weight of seeds is higher in black plastic closure than control and placement under trees. Thus black plastic closure of 2 hours per day for 2 weeks starting at 30 days can be recommended for peas planted on the long days.

\section{REFERENCES}

Bernier, G., Havelange, A., Houssa, C., Petitjean, A., \& Lejeune, P. (1993). Physiological signals that induce flowering. Plant Cell, 5, 1147-1155. doi: 10.1105/tpc.5.10.1147

Chairudin, Efendi, \& Sabaruddin. (2015). Dampak Naungan Terhadap Perubahan karakter Agronomi dan Morfo-fisiologi daun pada tanaman kedelai. Floratek, 10(1), 26-35.
Cobley, L. S. (1977). An introduction to the botany of tropical crops. London, UK: Longmans.

Dong, W., Zhang, Y., Zhang, Y., Ren, S., Wei, Y., \& Zhang, Y. (2016). Short-day photoperiod effects on plant growth, flower bud differentiation, and yield formation in adzuki bean (Vigna angularis). International Journal of Agriculture and Biology, 18(2), 337-345. doi: 10.17957/IJAB/15.0091

Guilioni, L., Wery, J., \& Tardieu, F. (1997). Heat stress-induced abortion of buds and flowers in pea: Is sensitivity linked to organ age or to relations between reproductive organs? Annals of Botany, 80(2), 159-168. doi: 10.1006/anbo.1997.0425

Harris, R. W. (1992). ROOT-SHOOT RATIOS. Journal of Arboriculture, 18(1), 39-42.

Kimani, E. N., Wachira, F. N., \& Kinyua, M. G. (2012). Molecular Diversity of Kenyan Lablab Bean (Lablab purpureus (L.) Sweet) Accessions Using Amplified Fragment Length Polymorphism Markers. American Journal of Plant Sciences, 3, 313-321. doi: 10.4236/ajps.2012.33037

Kofranek, A. M. (1980). Cut Chrysanthemums. In R. Larson (Ed.), Introduction to Floriculture. New York, USA: Academic Press.

Kramer, P. J., \& Kozlowski, T. T. (1979). Physiology of woody plants. New York, USA: Academic Press.

Kukade, S. A., \& Tidke, J. A. (2014). Reproductive Biology Of Dolichos Lablab L. (Fabaceae). Indian Journal of Plant Sciences, 3(2), 22-25.

Lang, A. (1965). Physiology of flower initiation. In A. Lang (Ed.), Differentiation and Development (pp. 1380-1536). Berlin, Heidelberg: Springer.

Loveless, A. R. (1991). Prinsip-prinsip biologi tumbuhan untuk daerah tropis. (K. Kartawinata, S. Danimiharja, \& U. Soetisna, Eds.). Jakarta, Indonesia: Gramedia Pustaka Utama.

Mao, A. A., \& Hynniewta, T. M. (2000). Floristic diversity of North East India. Journal of Assam Science Society, 41(4), 255-266.

Müller-Moulé, P., Golan, T., \& Niyogi, K. K. (2004). Ascorbate-Deficient Mutants of 
Arabidopsis Grow in High Light Despite Chronic Photooxidative Stress. Plant Physiology, 134(3), 1163-1172.

Nelza, A. (2016). Studi fenologi, karakter hasil dan mutu benih tanaman kacang koro pedang (Canavalia ensiformis L.) pada perbedaan kondisi naungan dan pemupukan. Institut Pertanian Bogor.

Parmar, A. M., P., A. S., Dhillon, N. P. S., \& Jamwal, M. (2013). Genetic variability of morphological and yield traits in Dolichos bean (Lablab purpureus L.). World Journal of Agricultural Sciences, 9(1), 24-28. doi: 10.5897/ajar2012.0033

Ramanujam, S., \& Singh, S. P. (1981). Pigeonpea breeding in the all India coordinated programme. In Proceedings of the International Workshop on Pigeonpeas. Patancheru. India: ICRISAT.

Salisbury, F. B., \& Ross, C. W. (1995). Fisiologi tumbuhan. Bandung, Infonesia: ITB Press.
Supriyono. (2007). Kajian Biologi dan Agronomi Kara benguk (Mucuna pruriens(L)DC) sebagai Tanaman Pangan dan Penutup Tanah. UGM.

Supriyono. (2012). Kendala Panjang Hari pada Pembungaan Kacang Tunggak (Vigna unguiculata L.) dan Usaha Mengatasinya. In SemNas Dies UNS 36 (pp. 306-316). Surakarta, Indonesia: UNS Press.

Wanjari, K. B., \& Rathod, S. T. (2012). Exploitation of heterosis through $\mathrm{F} 1$ hybrid in pigeonpea (Cajanus cajan L.): The status and prospects. Indian Journal of Genetics and Plant Breeding, 72(3), 257-263.

Wilkins, M. B. (1989). Advanced Plant Physiology. Harlow, UK: Longman. 